Abstracta Iranica Abstracta Iranica

Revue bibliographique pour le domaine irano-aryen

Volume 26 | 2005

Comptes rendus des publications de 2003

\title{
Les civilisations du Proche-Orient ancien. École du Louvre - Réunion des musées nationaux, Paris, 2003, 678 p., nbs ill.
}

\section{Astrid Nunn}

\section{(2) OpenEdition}

Journals

Édition électronique

URL : http://journals.openedition.org/abstractairanica/2928

DOI : 10.4000/abstractairanica.2928

ISSN : 1961-960X

Éditeur :

CNRS (UMR 7528 Mondes iraniens et indiens), Éditions de l'IFRI

\section{Édition imprimée}

Date de publication : 15 mai 2005

ISSN : 0240-8910

Référence électronique

Astrid Nunn, «Les civilisations du Proche-Orient ancien. École du Louvre - Réunion des musées

nationaux, Paris, 2003, 678 p., nbs ill. », Abstracta Iranica [En ligne], Volume 26 | 2005, document 54, mis en ligne le 08 décembre 2005, consulté le 25 septembre 2020. URL : http://

journals.openedition.org/abstractairanica/2928; DOI : https://doi.org/10.4000/abstractairanica.2928

Ce document a été généré automatiquement le 25 septembre 2020.

Tous droits réservés 


\title{
Les civilisations du Proche-Orient ancien. École du Louvre - Réunion des musées nationaux, Paris, 2003, 678 p., nbs ill.
}

\author{
Astrid Nunn
}

1 Écrire un manuel sur l'archéologie du Proche Orient ancien est un défi qu'A. Benoit a parfaitement relevé. En effet quels objets choisir dans l'immense richesse qu'offrent ces civilisations étalées sur un territoire et un laps de temps si vastes? Les premières « Notices» $\left(n^{\circ}\right.$ 101-103) sur l'Iran achéménide portent sur la résidence de Pasargades. Suivent celles sur Bisotun, Persépolis et la tombe de Suse. Les textes descriptifs et explicatifs offrent un aperçu aussi exhaustif que le permet la place qui leur est réservée et sont complétés par des reconstructions et des extraits de textes anciens. Signalons que le Levant achéménide n'est représenté que par le sarcophage d'Eshmunazar II (ce roi de Sidon a vraisemblablement régné un peu avant la date indiquée dans le texte) et que la tombe achéménide de Umm Udheinah, située à l'ouest d'Amman, est brièvement citée à la p. 610 .

\section{INDEX}

Thèmes : 3.0. Généralités

nompropre Persepolis, Pasargades, Pasargadae, Bisotun, Suse, Achaemenid, achéménides 
AUTEURS

ASTRID NUNN

Université de Munich 